\title{
Acute and Repeated Swim Stress Effects on Peripheral Benzodiazepine Receptors in the Rat Hippocampus, Adrenal, and Kidney
}

Avi Avital, M.A., Gal Richter-Levin, Ph.D., Svetlana Leschiner, Ph.D., Ilana Spanier, B.Sc., Leo Veenman, Ph.D., Abraham Weizman, M.D., and Moshe Gavish, Ph.D.

Peripheral benzodiazepine receptor (PBR) density has been found to be sensitive to stress. We set out to compare the influences of acute and repeated swim stress on behavior and PBR density. Following acute and repeated swim stress, rats were tested in an elevated plus-maze and an open-field test for anxiety levels, and tissues were collected from the adrenal gland, kidney, and hippocampus for measurements of PBR density. The acute rather than the repeated stress led to robust alterations in $P B R$ density. The largest reduction in hippocampal and adrenal gland PBR density was found one hour after acute stress. In the hippocampus, acute stress caused a biphasic change in PBR density: a robust reduction in PBR density one hour after the acute stress and a distinct elevation in PBR density at 24 hours, while 72 hours after stress the elevation in PBR density appeared to be reduced.

[Neuropsychopharmacology 25:669-678, 2001] (C) 2001 American College of Neuropsychopharmacology. Published by Elsevier Science Inc.
KEY WORDS: Stress; Swim stress; Anxiety; Peripheral benzodiazepine receptors

Benzodiazepines are anxiolytics, anticonvulsants, muscle relaxants, and sedative-hypnotics. These therapeutic effects are mediated by the central benzodiazepine receptors (CBR) via coupling to $\gamma$-aminobutyric acid type A $\left(\mathrm{GABA}_{\mathrm{A}}\right)$ receptors and chloride ion channels

From the Department of Psychology, University of Haifa, Haifa, Israel (AA, GR-L), the Department of Pharmacology, The Bruce Rappaport Faculty of Medicine, Technion-Israel Institute of Technology, Haifa, Israel (SL, IS, LV, MG), the Geha Mental Health Center, Felsenstein Medical Research Center, Rabin Medical Center, Beilinson Campus, Petah Tiqva (AW), and the Sackler Faculty of Medicine, Tel Aviv University, Tel Aviv, Israel (AW).

Address correspondence to: Moshe Gavish, Ph.D., Department of Pharmacology, The Bruce Rappaport Faculty of Medicine, Technion-Israel Institute of Technology, P.O.B. 9649, 31096 Haifa, Israel. Tel.: +972-4-829-5275; Fax: +972-4-851-3145; e-mail: mgavish@ tx.technion.ac.il.

Received November 30, 2000; revised April 12, 2001; accepted May 8, 2001.

Online publication: 5/9/01 at www.acnp.org/citations/Npp 050901118.
(Möhler and Okada 1977; Squires and Braestrup 1977). Subsequent studies have described another distinct class of binding sites for benzodiazepines that have been found in both peripheral tissues and the central nervous system (CNS). These membrane binding sites have been shown to have physiological functions and fulfill generally accepted criteria for a pharmacological receptor (Mestre et al. 1985), and therefore they have been termed peripheral benzodiazepine receptors (PBR) (Verma and Snyder 1989). PBRs differ from CBRs in their lack of coupling to $\mathrm{GABA}_{\mathrm{A}}$ receptors and in their ligand specificity: PBRs exhibit high affinity for Ro 5-4864 (4'-chlorodiazepam) or PK 11195 (an isoquinoline carboxamide derivative), but low affinity to clonazepam. The reverse is true for CBRs (Le Fur et al. 1983; Gavish et al. 1992).

The possibility that PBRs are involved in the regulation of endocrine activity has been suggested by Anholt et al. (1987). It has been shown, for example, that endocrine organs are extremely rich in PBRs (Bénavidès et al. 1984; De Souza et al. 1985). In the adrenal gland, 
PBRs are abundant in the cortex (which is involved in corticosteroid synthesis and in response to stress) and absent in the medulla (Bénavidès et al. 1984; De Souza et al. 1985). The modulatory effect of stress on PBR density has been examined in several animal models and in some human studies (Holmes et al. 1992; Gavish et al. 1993; Weizman and Gavish 1993). The reports so far indicate a bidirectional effect of various stress models on PBR density in various tissues, especially in the adrenal gland and kidney: an increase in PBR density after acute stress (Drugan et al. 1986; Basile et al. 1987; Okun et al. 1988; Karp et al. 1989) and a decrease in PBR density after repeated stress (Drugan et al. 1986, 1987; Weizman et al. 1990a; Dar et al. 1991).

In order to further elucidate the involvement of PBRs in stress and post-stress syndromes, we set out to compare the influences of single (acute) and repeated (chronic) stress on behavior and PBR density. Repeated swim stress (RSS) has been found to be a useful chronic stress animal model in assessing the impact of repeated stress on PBR expression in the kidney (Burgin et al. 1996). In the present study, acute swim stress (ASS) included only a single 15-min swim, whereas the RSS included a 15-min swim once daily for 20 consecutive days. The behavioral consequences of exposure to the different stressors (RSS and ASS) were compared, as well as their effects on PBR density in adrenal gland, kidney, and hippocampus.

There have been various reports suggesting a pivotal role of PBRs in the adrenal gland (Papadopoulos et al. 1998; Weizman et al. 1999; Zelena et al. 1999; Zilz et al. 1999) and in the kidney (Drugan et al. 1988, 1990; Holmes and Drugan 1994; Lehmann et al. 1999) in the regulation of stress responses. Furthermore, the hippocampus has been hypothesized to play a role in the basal tone of the hypothalamic-pituitary-adrenal axis (HPA) and in the magnitude and duration of stress responses (Vázquez et al. 1996). Therefore, we chose these organs to study the temporal profiles of changes in PBR densities related to stress and subsequent behavioral changes.

In one experiment, behavioral changes in a plusmaze and an open-field test were determined $40 \mathrm{~min}$ utes after exposure to either ASS or RSS. Ligand binding to PBRs in the adrenal gland, hippocampus, and kidney was determined 24 hours after ASS or RSS. In a second experiment, 1, 24, and 72 hours following exposure to ASS, we characterized the temporal profile of behavioral changes and of PBR density alteration in the adrenal gland and hippocampus.

\section{MATERIALS AND METHODS}

\section{Animals}

Adult male Sprague-Dawley rats $(n=108)$ weighing between 240 and $270 \mathrm{~g}$ were purchased from Harlan
(Jerusalem, Israel) and housed four per cage in $75 \times 55 \times$ $15 \mathrm{~cm}$ Plexiglas cages in temperature-controlled $(23 \pm$ $1^{\circ} \mathrm{C}$ ) animal quarters on a 12:12 light-dark cycle (lights on 7 A.M.-7 P.M.). They had access to standard Purina Rat Chow pellets and water ad libitum. The Haifa University Animal Care and Use Committee approved the study.

\section{Behavior}

Water Maze. The water maze used consisted of a circular pool of water $(1.7 \mathrm{~m}$ in diameter with a rim $50 \mathrm{~cm}$ high). Water depth was $30 \mathrm{~cm}$, and temperature was maintained at $23 \pm 1{ }^{\circ} \mathrm{C}$.

Repeated Swim Stress (RSS) Procedure. Rats were subjected to RSS as previously described (Burgin et al. 1996). Briefly, individual rats were allowed 15 minutes to swim in the water maze once daily for 20 consecutive days. Each day, following exposure to the maze, the rats were allowed to dry in a resting cage for 40 minutes before being returned to their home cage. After the last swim session and 40-min stay in the resting cage, the rats were subjected to post-stress behavioral tests.

Acute Swim Stress (ASS) Procedure. The ASS procedure was modified from the RSS procedure described above. The specific change was that the individual rats were subjected to only a single 15-min swim session in the water maze, instead of such swim sessions on 20 consecutive days. After this single swim session, rats were allowed to dry for 40 minutes in a resting cage until commencing the post-stress tests.

Elevated Plus-Maze. The elevated plus-maze (Pellow et al. 1985), which consisted of four arms (75 cm each) on a stand $50 \mathrm{~cm}$ high, was positioned in a dimly lighted room. The floor of the maze was white. Two of the arms had no railing (open arms), and the other two arms were protected by a opaque railings (painted black) $10 \mathrm{~cm}$ high (closed arms). The rats were placed in the center of the maze. Subsequently, the time that the rats spent on each of the different arms, the number of entries to the closed and open arms, and the number of instances of rearing were manually recorded for a period of five minutes.

Open-Field Test. The open-field test was carried out according to methods described previously (Carli et al. 1989; Lemoine et al. 1990). Briefly, the open field consisted of a wooden box $90 \times 90 \times 38 \mathrm{~cm}$. The walls were painted black and the floor was white and divided by 1$\mathrm{cm}$-wide black lines into 25 squares $17 \times 17 \mathrm{~cm}$. Rats were placed at the corner of the open field. Subsequently, for a period of five minutes, the number of entries into the central and the peripheral squares, the time that the rats spent in both areas, and the number of instances of rearing were manually recorded. 
Behavioral Index for Anxiety Forty minutes following the last exposure to stress, all rats were examined in the open field and the elevated plus-maze in a counterbalanced order. Both the elevated plus-maze and the open-field test may give an indication of the level of anxiety (Stout and Weiss 1994; Calvo-Torrent et al. 1999). In the elevated plus-maze, the number of instances of rearing (Song et al. 1995; Pandossio et al. 2000), the ratio between the time spent in the open and closed arms, and the relative number of entries, are considered measures of anxiety level (Broadhurst 1975). In the open-field test, the number of instances of rearing (Ferretti et al. 1995; Harris et al. 1997), the ratio between the time spent along the walls and the time spent in the center, or the number of square crossings along the walls relative to the number of square crossings in the center, is also considered a measure of anxiety (Angrini et al. 1998).

In the present study, the measures from both the elevated plus-maze and the open-field test showed considerable overlap. In order to simplify presentation and still encompass the behavioral changes in both mazes, we computed a behavioral index for anxiety.

We measured: (1) the time difference (seconds): closed minus open in the elevated plus-maze and peripheral minus central in the open field; (2) the total crossings: the number of entrances to the closed plus open areas of the elevated plus-maze and peripheral plus central areas of the open field; and (3) the number of instances of rearing in the elevated plus-maze and open field. The performance of each rat in the experimental groups, in each measure, was expressed as a percentage relative to the averaged score of the control group. We then averaged the percentage scores of all the measures into a behavioral index for each rat. High score on the behavioral index was indicative of high levels of anxiety.

\section{Radioligand Binding Assay}

Twenty-four hours after the last exposure to the water maze, the rats were decapitated and the adrenal glands, kidneys, and hippocampus were dissected, snap-frozen in liquid nitrogen, and stored at $-70^{\circ} \mathrm{C}$ until further use Weizman et al. 1989, 1990a,b). The adrenal glands ( $\mathrm{n}=$ $8)$, kidneys $(n=8)$, and hippocampus $(n=6)$ were weighed and homogenized separately in $20 \mathrm{ml}$ of 0.05 $\mathrm{M}$ Tris- $\mathrm{HCl}$ buffer, $\mathrm{pH} 7.4$, at $4^{\circ} \mathrm{C}$ with a Kinematica Polytron (setting 5) for 15 seconds. The homogenate was centrifuged at $37,000 \mathrm{~g}$ for 15 minutes at $4^{\circ} \mathrm{C}$, and the pellet was suspended in 50 volumes of $0.05 \mathrm{M}$ potassium phosphate buffer, $\mathrm{pH} 7.4$, and used for binding studies for PBRs.

$\left[{ }^{3} \mathrm{H}\right] \mathrm{PK} 11195$ binding to PBRs in the above organs was measured as described by Fares and Gavish (1986). The final volume of the binding assay was $500 \mu \mathrm{l}$ and contained $400 \mu \mathrm{l}$ of the suspension of the membranes (30-700 $\mu$ g protein) and $25 \mu \mathrm{l}\left[{ }^{3} \mathrm{H}\right] \mathrm{PK} 11195$ (six concentrations from 0.19 to $6.0 \mathrm{nM}$ ) in the absence (total binding) or presence (non-specific binding) of $75 \mu \mathrm{l}$ unlabeled PK 11195 (final concentration $1 \mu \mathrm{M}$ ). After incubation for 60 minutes at $4^{\circ} \mathrm{C}$; the reaction was terminated by filtration through Whatman GF/C filters, which were then washed three times with $5 \mathrm{ml}$ of 50 $\mathrm{mM}$ potassium phosphate buffer, $\mathrm{pH}$ 7.4. The filters were placed in vials containing $5 \mathrm{ml}$ of Opti-Fluor (Packard, Groningen, The Netherlands) and counted for radioactivity after 12 hours. Equilibration dissociation constant $\left(\mathrm{K}_{\mathrm{d}}\right)$ and maximal number of binding sites $\left(B_{\max }\right)$ were determined by Scatchard analysis of saturation curves of $\left[{ }^{3} \mathrm{H}\right] \mathrm{PK} 11195$ binding. The binding parameters were analyzed for each subject individually.

\section{Statistical Analysis}

One-way analysis of variance (ANOVA) followed by Student-Newman-Keuls post hoc multiple comparison tests were used as indicated. All tests were two-tailed. Results are presented as means \pm SEM.

\section{RESULTS}

\section{Experiment 1: Comparison Between the Behavioral Consequences of ASS and RSS and Their Effects on PBR Density}

Behavioral Effects of ASS $(n=12)$ and RSS $(n=12)$. The stressor effects were evaluated by the behavioral index (Figure 1). One-way ANOVA revealed a significant treatment effect $(\mathrm{F}[2,33]=16.317 ; p<.0001)$. Post hoc Student-Newman-Keuls tests revealed that the RSS procedure significantly increased the anxiety level relative to the control $(p<.001)$, while the ASS procedure resulted in a significantly higher anxiety level than both the control $(p<.001)$ and RSS $(p<.05)$ groups.

Comparison between Effects of ASS and RSS and PBR Density in Adrenal Gland, Kidney, and Hippocampus. Under the conditions described, analysis of $\left[{ }^{3} \mathrm{H}\right] \mathrm{PK}$ 11195 binding to adrenal membranes showed that specific binding was around $80 \%$ of total binding. One-way ANOVA revealed a significant treatment effect in the adrenal gland $(\mathrm{F}[2,21]=68.59 ; p<.0001$; Figure 2, Panel A). Comparing ASS animals to control animals revealed a significant $30 \%$ decrease in $\left.{ }^{3} \mathrm{H}\right] \mathrm{PK} 11195$ binding density $\left(\mathrm{B}_{\max }=32,037 \pm 488\right.$ vs. $45,490 \pm 888$ $\mathrm{fmol} / \mathrm{mg}$ protein; $p<.001)$, with no significant difference in the apparent affinity $\left(\mathrm{K}_{\mathrm{d}}=3.3 \pm 0.3\right.$ vs. $3.8 \pm 0.3$ $\mathrm{nM})$. Likewise, a significant $28 \%$ reduction in density was found in ASS vs. RSS rats $\left(B_{\max }=32,037 \pm 488\right.$ vs. 


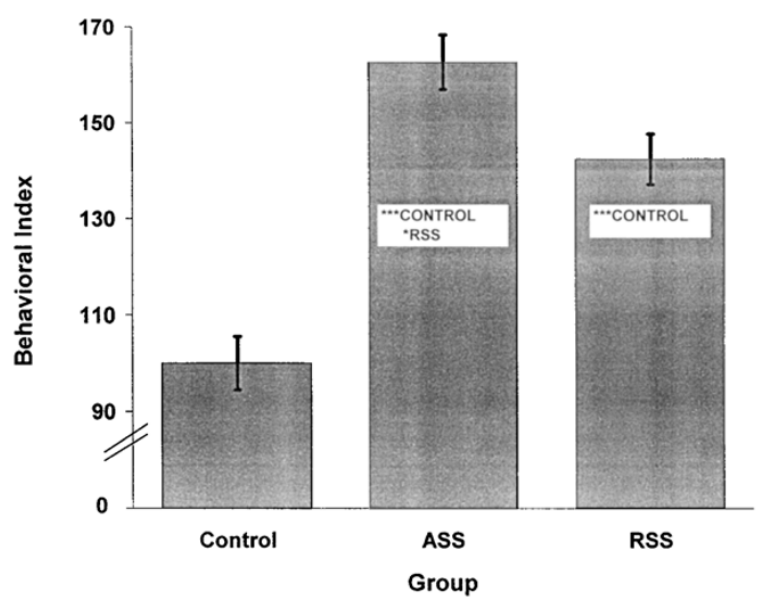

Figure 1. Behavioral effects of ASS and RSS. Forty minutes after the last exposure to ASS or RSS, rats were tested in the elevated plus-maze and open field, and a behavioral index for anxiety was calculated (see Methods for details). The behavioral index of both the ASS and the RSS groups was significantly higher than that of the controls $\left({ }^{* *} p<.001\right)$. The ASS group showed the most robust increase in behavioral index $\left({ }^{*} p<.05\right.$, vs. RSS group).

$44,189 \pm 1,175 \mathrm{fmol} / \mathrm{mg}$ protein; $p<.001)$, with no significant difference in the apparent affinity $\left(\mathrm{K}_{\mathrm{d}}=3.3 \pm\right.$ 0.2 vs. $3.4 \pm 0.2 \mathrm{nM}$ ).

Regarding $\left[{ }^{3} \mathrm{H}\right] \mathrm{PK} 11195$ binding to renal membranes, specific binding was around $90 \%$ of total binding, under the conditions described. One-way ANOVA also revealed a significant treatment effect on renal PBR density $(F[2,21]=210.78 ; p<.0001$; Figure 2, Panel B). Scatchard analysis of $\left[{ }^{3} \mathrm{H}\right] \mathrm{PK} 11195$ binding to renal membranes from ASS vs. control animals revealed a significant $37 \%$ decrease in density $\left(B_{\max }=5,998 \pm 121\right.$ vs. $9,447 \pm 138 \mathrm{fmol} / \mathrm{mg}$ protein; $p<.001$ ), with no significant difference in the apparent affinity $\left(\mathrm{K}_{\mathrm{d}}=2.06 \pm\right.$ 0.13 vs. $2.07 \pm 0.13 \mathrm{nM}$ ). Likewise, there was a significant $23 \%$ reduction in density in ASS vs. RSS rats $\left(B_{\max }=\right.$ $5,998 \pm 121$ vs. $7,769 \pm 92 \mathrm{fmol} / \mathrm{mg}$ protein; $p<.001)$, with no significant difference in the apparent affinity $\left(K_{d}=2.06 \pm 0.13\right.$ vs. $\left.1.9 \pm 0.2 \mathrm{nM}\right) .\left[{ }^{3} \mathrm{H}\right] \mathrm{PK} 11195$ binding to renal membranes from RSS vs. control rats revealed a significant $18 \%$ decrease in density $\left(B_{\max }=\right.$ $7,769 \pm 92$ vs. $9.447 \pm 138 \mathrm{fmol} / \mathrm{mg}$ protein; $p<.001)$, with no significant difference in the apparent affinity $\left(K_{d}=1.9 \pm 0.2\right.$ vs. $\left.2.07 \pm 0.13 \mathrm{nM}\right)$.

In the hippocampus, we found that specific $\left[{ }^{3} \mathrm{H}\right] \mathrm{PK}$ 11195 binding was around $60 \%$ of total binding, under the conditions described. Similarly to the adrenal and kidney, one-way ANOVA revealed a significant treatment effect on PBR density in the hippocampus $(F[2,15]=$ 227.72; $p<.0001$; Figure 2, Panel C). Scatchard analysis of $\left[{ }^{3} \mathrm{H}\right] \mathrm{PK} 11195$ binding to hippocampal membranes from ASS vs. control rats revealed a significant $141 \%$ increase in density $\left(B_{\max }=222 \pm 7\right.$ vs. $92 \pm 5$
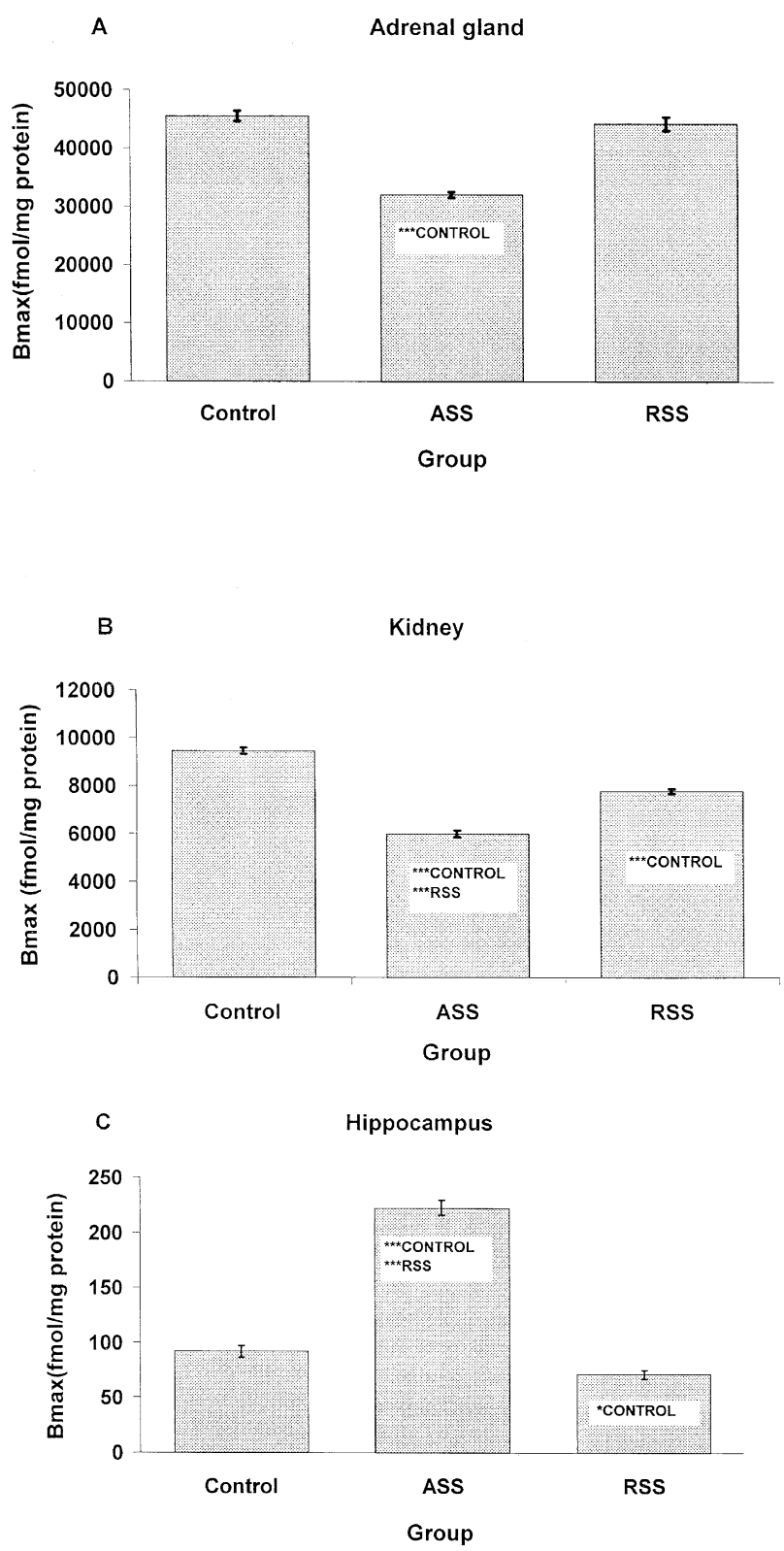

Figure 2. Effects of ASS and RSS on PBR density in adrenal gland (Panel A), kidney (Panel B), and hippocampus (Panel C). Twenty-four hours after the last exposure to stress, the effects of ASS or RSS on $B_{\max }$ values of $\left[{ }^{3} \mathrm{H}\right] \mathrm{PK} 11195$ were measured in each organ. In the adrenal gland (Panel A), only in the ASS was there a significant reduction in $\mathrm{B}_{\max }$ values $\left({ }^{* * *} p<.001\right)$. In the kidney (Panel B), both ASS and RSS resulted in a reduction in $B_{\max }$ values compared with control, but the ASS was significantly more potent than the RSS $\left({ }^{* * *} p<.001\right)$. In the hippocampus (Panel C), the RSS group showed a reduction in $B_{\max }$ values, but the ASS group showed an opposite effect $\left({ }^{*} p<.05,{ }^{* * *} p<.001\right)$.

$\mathrm{fmol} / \mathrm{mg}$ protein; $p<.001)$, with no significant difference in the apparent affinity $\left(\mathrm{K}_{\mathrm{d}}=2.2 \pm 0.1 \mathrm{vs.} 2.3 \pm 0.2\right.$ $\mathrm{nM})$. In contrast, $\left[{ }^{3} \mathrm{H}\right] \mathrm{PK} 11195$ binding to hippocampal membranes from RSS vs. control animals revealed a significant $23 \%$ decrease in PBR density $\left(B_{\max }=71 \pm\right.$ 
4 vs. $92 \pm 5 \mathrm{fmol} / \mathrm{mg}$ protein; $p<.001)$, with no significant difference in the apparent affinity $\left(\mathrm{K}_{\mathrm{d}}=2.0 \pm 0.2\right.$ vs. $2.3 \pm 0.2 \mathrm{nM}$ ). Comparison of ASS with RSS animals showed a significant $213 \%$ increase in density $\left(B_{\max }=\right.$ $222 \pm 7$ vs. $71 \pm 4 \mathrm{fmol} / \mathrm{mg}$ protein; $p<.001$ ), with no significant difference in the apparent affinity $\left(\mathrm{K}_{\mathrm{d}}=2.2 \pm\right.$ 0.1 vs. $2.0 \pm 0.2 \mathrm{nM})$.

ASS and RSS Behavioral Index Correlated with Alterations in PBR Density. The anxiety level of the ASS animals, as evaluated by the behavioral index, showed a significant negative correlation with PBR density change in the adrenal gland $(\mathrm{r}=-0.84 ; p<.001$, Pearson test). Likewise, a significant negative correlation was found between the ASS behavioral index and the PBR density change in the kidney $(\mathrm{r}=-0.87 ; p<.0001$, Pearson test). In contrast, the correlation between the ASS behavioral index and the PBR density change in the hippocampus was significantly positive $(\mathrm{r}=0.85$; $p<$ .0005 , Pearson test). The only significant (and negative) correlation for the RSS group was found between the RSS behavioral index and the PBR density change in the kidney $(\mathrm{r}=-0.72 ; p<.0009$, Pearson test).

\section{Experiment 2: Temporal Profile of ASS Effects on Behavior and PBR Density}

In the first experiment, rats were exposed to either ASS or RSS. Both stress protocols affected behavior as well as PBR density. However, the ASS resulted in more severe behavioral effects and more robust alterations in PBR density, suggesting that adaptation processes may also play a role in the repeated stress procedure. Therefore, in the second experiment we characterized the temporal profile of PBR density alterations 1, 24, and 72 hours following ASS. To simplify the experimental design, and since our main interest was the HPA axis, we focused on the adrenal gland and hippocampus in this second experiment.

Temporal Profile of ASS Effects on Behavior. In order to examine the temporal profile of ASS effects on behavior, rats were tested 1, 24, or 72 hours post-ASS. One-way ANOVA revealed a significant time effect on behavior $(\mathrm{F}[3,27]=20.878 ; p<.0001$; Figure 3$)$. Post hoc Student-Newman-Keuls tests revealed that the ASS procedure significantly increased the level of anxiety, as measured by the behavioral index 1 hour post-stress, relative to controls $(p<.001)$. However, the behavioral index of rats 24 hours post-ASS was significantly lower than that at 1 hour $(p<.001)$, although still higher than controls $(p<.001)$. Likewise, at 72 hours post-ASS, the behavioral index was significantly higher than controls $(p<.01)$, but significantly lower than that at 1 hour post-ASS $(p<.001)$.

Temporal Profile of ASS Effects on PBR Density in Adrenal Gland and Hippocampus. In order to assess

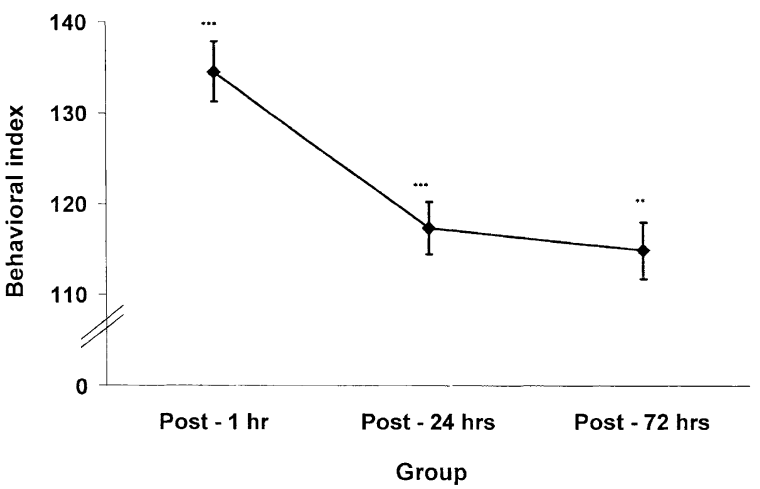

Figure 3. Anxiety level of ASS group as evaluated by the behavioral index 1, 24, and 72 hours after exposure to the ASS procedure. ${ }^{* *} p<.01,{ }^{* * *} p<.001$, vs. control group.

the temporal profile of ASS effects on PBR density, the adrenal gland and hippocampus were dissected 1, 24, or 72 hours post-ASS, and the tissues were processed for binding assays. The percentage of specific binding of $\left[{ }^{3} \mathrm{H}\right] \mathrm{PK} 11195$ vs. total binding was similar to what was found in experiment 1 .

One-way ANOVA revealed a significant time effect on PBR density in the adrenal gland $(\mathrm{F}[3,27]=42.525 ; p<$ .0001; Figure 4, Panel A). Post hoc Student-NewmanKeuls tests revealed that the ASS procedure significantly decreased PBR density, as measured 1 hour post-stress, relative to the controls $(62 \% ; p<.001)$. Twenty-four hours post-ASS, the decrease in PBR density was much less, but still significantly lower than controls $(33 \%$; $p<$ .001). In addition, the PBR density of rats 24 hours postASS was significantly higher than that of the rats 1 hour post-ASS $(1 \% ; p<.001)$. Seventy-two hours post-ASS, PBR density was still significantly lower than controls $(17 \% ; p<.01)$, but significantly higher than that of the rats 1 hour post-ASS $(54 \% ; p<.001)$ and animals 24 hours post-ASS $(24 \% ; p<.001)$.

One-way ANOVA revealed a significant time effect on PBR density in the hippocampus (F[3,27] = 173.03; $p<$ .0001; Figure 4, Panel B). Post hoc Student-NewmanKeuls tests revealed that the ASS procedure had a biphasic effect on PBR density in the hippocampus. It significantly decreased PBR density at 1 hour post-stress $(64 \% ; p<.001)$, but PBR density 24 hours post-ASS was significantly higher than that of the controls $(65 \%$; $p<$ .001). At 72 hours post-ASS, although still significantly higher than controls $(50 \% ; p<.001)$, PBR density was significantly lower than at 24 hours $(42 \% ; p<.001)$.

\section{DISCUSSION}

The results of the current study provide evidence of marked changes in PBR density in various tissues as a result of exposure to a behavioral stressor. In addition, 

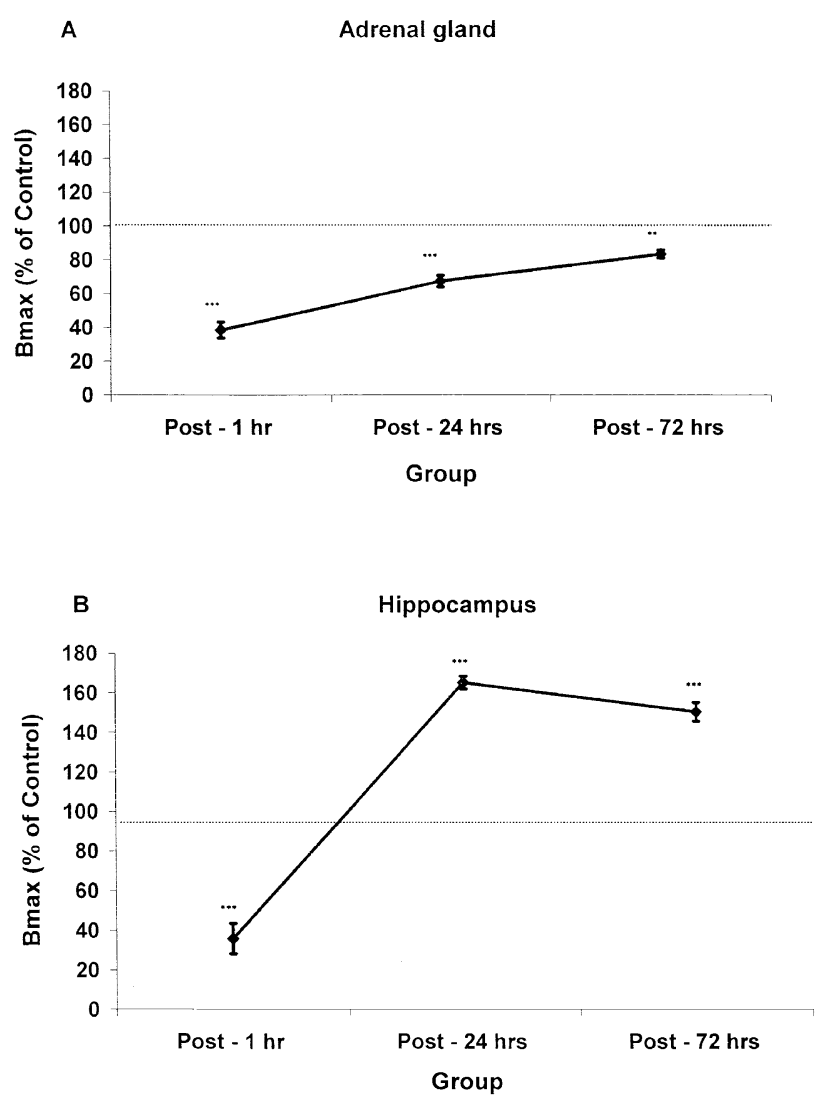

Figure 4. Temporal profile of ASS effects on PBR density in the adrenal gland (A) and hippocampus (B). The effects of the ASS on $B_{\max }$ values of $\left[{ }^{3} \mathrm{H}\right] \mathrm{PK} 11195$ in each organ were examined after 1, 24, and 72 hours and are presented as a percentage of the control group $\left({ }^{* *} p<.01,{ }^{* * *} p<.001\right)$.

the results demonstrate significant differences between the effects of acute or repeated stress. These changes are tissue-specific, as previous observations indicated (Drugan et al. 1986; Basile et al. 1987; Novas et al. 1987; Rägo et al. 1989; Ferrarese et al. 1991; Holmes et al. 1992). In particular, the present results shed light on the nature of PBR reactivity to swim stress in both brain and peripheral tissues, i.e. hippocampus vs. adrenal and kidney.

Experiment 1 of our study showed that the ASS rather than the RSS procedure resulted in the most prominent alterations in behavior and PBR density, as measured 24 hours post-stress, in the adrenal gland, hippocampus, and kidney. Both the ASS and the RSS induced a significant elevation of anxiety level, as measured in the elevated plus-maze and the open-field test. In addition, the ASS induced a significant reduction in renal and adrenal PBR density, but a significant elevation of hippocampal PBR density. The RSS procedure induced a significant reduction in renal and hippocampal PBR density 24 hours post-stress, but did not alter PBR density in the adrenal. Thus, while the results from the ASS procedure suggest that PBR density in the adrenal gland, hippocampus, and kidney may be correlated with anxiety levels after acute stress, the results from the RSS procedure suggest that only the renal and hippocampal PBR density may be related to anxiety levels after chronic stress.

The reduction in renal PBR density 24 hours following RSS is consistent with previous data indicating a reduction in renal PBR density following repeated or chronic stress (Drugan et al. 1986, 1987; Weizman et al. 1990a; Rägo et al. 1991). In particular, Burgin et al. (1996) previously found a reduction in renal PBR after rats were subjected to 21 days of forced daily swimming. The selective decrease in renal PBR may be ascribed to activation of the renin-angiotensin system during repeated stress, as suggested by Holmes et al. (1992) and Holmes and Drugan (1994). This reduction in renal PBR density 24 hours after RSS also might be related to the repeated pattern of exposure to the swim stress. This repetition might activate a habituation process that tends to an adaptive decrease in sympathetic tone (Burgin et al. 1996). As suggested by Drugan (1996), the reduction may represent a compensatory shift in receptors to accommodate a new behavioral/physiological baseline in comparison with normal controls.

The reduction in hippocampal PBR density 24 hours following RSS was somewhat surprising, since to our knowledge the effect of chronic stress on hippocampal PBR density was not reported previously. Nonetheless, upregulation of hippocampal PBR density following acute stress and downregulation following chronic stress is consistent with what has been reported previously regarding the effects of acute and chronic stress on PBR density in the CNS in general (for review, see Gavish et al. 1999). Interestingly, Drugan et al. (1995) reported that hippocampal PBR binding is up-regulated following an injection of an anxiogenic beta-carboline. The up-regulation suggests that such injections provoke acute stress. Furthermore, the hippocampus appears to be a brain region in which PBR density is particularly sensitive to systemic neurotoxic challenges (Lallement et al. 1993; Guilarte et al. 1995; Kuhlmann and Guilarte 1997; Veenman and Gavish 2000). Thus, our behavioral stress model may provide a relevant paradigm for the study of stress-related changes in nervous tissue.

Since ASS was the more effective stress protocol in the first experiment, we examined the temporal profile (at 1, 24, or 72 hours post-stress) on anxiety levels after ASS in a second experiment. Since our primary interest was a potential relationship between the role of PBRs in the HPA axis and behavior, the tissues of choice in the second experiment were the adrenal and hippocampus. One hour post-stress, the ASS procedure induced a strong and significant elevation in anxiety level, which was less profound but still significant 24 and 72 hours post-stress. Furthermore, ASS induced a significant re- 
duction in adrenal PBR density 1 hour post-stress that was still significant 24 and 72 hours post-stress.

Interestingly, ASS induced a biphasic change in PBR density in the hippocampus: a significant reduction in PBR density 1 hour post-stress, followed by a significant elevation 24 hours post-stress that was still significant 72 hours post-stress. While the behavioral index temporal profile was similar to that of the PBR density alterations in the adrenal, this was not obvious for the PBR density change in the hippocampus. These results suggest that the changes in PBR density in the adrenal are closely related to the alterations of behavior in the present study, while the change in hippocampal PBR density presents a more complex picture. Since the results of experiment 1 suggested that the hippocampus may be a structure representative of PBR changes in the CNS due to stress, we believe that the relevance to behavior of PBR density changes in the hippocampus merits further study.

Considering the PBR synthesis cascade (Zilz et al. 1999; Papadopoulos et al. 1997), the duration until novel synthesis and expression of PBRs can be expected to require more than one hour. This time frame suggests that changes in PBR ligand binding density in the adrenal and hippocampus within the first hour following stress, as reported in the present study, are rather due to recruitment or disbanding of functional PBRs than to modifications in PBR synthesis. Studies in our laboratory regarding PBR composition following various treatments suggest that PBR function, including PK 11195 binding, is related to the relative abundance of the $18 \mathrm{kDa}$ isoquinoline binding protein (IBP) PBR subunit within the PBR complex (Veenman and Gavish 2000; Golani et al., 2001). For example, castration of female rats by chronic administration of the GnRH agonist Decapeptyl (triptorelin-D-Trp ${ }^{6}-1 \mathrm{HRH}$ ) resulted in reduced PBR ligand binding in the adrenal accompanied by changes in PBR subunit composition (Golani et al., in press). Apparently, changes in PK11195 binding possibly may be due to association of more or fewer IBP subunits to the PBR complex. For short term changes this may imply that more or fewer "free" IBP present in the mitochondrial membrane may be transferred into the PBR complex. Longer term changes may include changes in PBR protein synthesis.

Interactions between corticosteroids and PBRs are often considered in responses to stress (for reviews, see Gavish et al. 1999; Veenman and Gavish 2000). PBRs appear to play a major role in the control of adrenal steroidogenesis during exposure to acute and chronic environmental stress (Gavish and Weizman 1997). Abundant evidence shows an increase in corticosterone following swim stress (Nagy et al. 1983; Cox et al. 1985; Shors et al. 1999; Shors 2001), including forced swim stress (Gonzalez et al. 1990; Moura and De Moraes 1994; Connor et al. 1997). Purdy et al. (1991) found that within 70 minutes after acute swim stress, increases in allopregnalonone and allotetrahydydrodeoxycorticosterone peaked in the cerebral cortex and in the hypothalamus of rats. This time course of corticoid synthesis in the CNS may correlate with the reduction of PBR binding found in first hour after acute swim stress in the hippocampus in our present study. A question remaining is whether this correlation in time is due to an actual effect of corticosteroids on PBR function.

Interestingly, it was also found that both GABA and benzodiazepine receptor levels were positively correlated with circulating corticosterone levels in female rats, but this was not true for male rats (Wilson and Biscardi 1994). In accord, one previous study showed that GABA-A and GABA-B receptors in hippocampus, cerebral cortex and cerebellum of male rats are not affected by either acute and repeated swim stress (Motohashi et al. 1993). In mice, in vivo binding of $\left[{ }^{3} \mathrm{H}\right] \mathrm{Ro} 15-1788$ to benzodiazepine receptors was decreased in the hippocampus, cerebral cortex, striatum, hypothalamus, and midbrain after repeated swim stress (Weizman et al. 1989). Such effects were not observed in adrenalectomized animals (Weizman et al. 1990b). Thus, only in some instances corticosteroids may affect GABA receptor and CBR function. In male rats, however, no obvious correlation appears to exist between changes in CBR, PBR and corticosteroid levels due to acute and repeated swim stress.

In conclusion, we suggest that PBR density in the adrenal gland and kidney is sensitive to environmental stress associated with significant threats to the organism and that these changes may play a role in the physiological and behavioral responses to stress. The role of the changes observed in the hippocampus is as yet unclear, but may be associated with the neuroendocrine response to stress.

\section{ACKNOWLEDGMENTS}

This work was supported by the V.P.R. Fund at the TechnionIsrael Institute of Technology and the University of Haifa, Haifa, Israel. The Center for Absorption in Science, Ministry of Immigrant Absorption, State of Israel, is acknowledged for their support to S.L and L.V. We thank Ruth Singer for editing the manuscript.

\section{REFERENCES}

Angrini M, Leslie JC, Shephard RA (1998): Effects of propranolol, buspirone, $\mathrm{pCPA}$, reserpine, and chlordiazepoxide on open-field behavior. Pharmacol Biochem Behav 59:387397

Anholt RRH, De Souza EB, Kuhar MJ, Basile AS, Weissman BA, Skolnick P (1987): Depletion of peripheral-type benzodiazepine receptors after hypophysectomy in rat adrenal gland and testis. Eur J Pharmacol 110:41-46 
Basile AS, Weissman BA, Skolnick P (1987): Maximal electroshock increases the density of $\left[{ }^{3} \mathrm{H}\right]$ Ro 5-4864 binding to muse cerebral cortex. Brain Res Bull 19:1-7

Bénavidès J, Begassat F, Phan T, Tur C, Uzan A, Renault C, Dubroeucq MC, Guérémy C, Le Fur G (1984): Histidine modification with diethylpyrocarbonate induces a decrease in the binding of an antagonist, PK 11195, but not of an agonist, RO5-4864, of the peripheral benzodiazepine receptors. Life Sci 35:1249-1256

Burgin R, Weizman R, Gavish M (1996): Repeated swim stress and peripheral-type benzodiazepine receptors. Neuropsychobiology 33:28-31

Broadhurst PL (1975): The Maudsley reactive and nonreactive strains of rats: a survey. Behav Genet 5:299-319

Calvo-Torrent A, Brain PF, Martinez M (1999): Effect of predatory stress on sucrose intake and behavior on the plus-maze in male mice. Physiol Behav 67:189-196

Carli M, Prontera C, Samanin R (1989): Effect of 5-HT $\mathrm{H}_{1 \mathrm{~A}}$ agonists on stress-induced deficit in open field locomotor activity of rats: Evidence that this model identifies anxiolytic-like activity. Neuropharmacology 28:471-476

Connor TJ, Kelly JP, Leonard BE (1997): Forced swim testinduced neurochemical endocrine, and immune changes in the rat. Pharmacol Biochem Behav 58: 961-967

Cox RH, Hubbard JW, Lawler JE, Sanders BJ, Mitchell VP (1985): Cardiovascular and sympathoadrenal responses to stress in swim-trained rats. J Appl Physiol 58:12071214

Dar DE, Weizman A, Karp L, Grinshpoon A, Bidder M, Kotler M, Tyano S, Bleich A, Gavish M (1991): Platelet peripheral benzodiazepine receptors in repeated stress. Life Sci 48:341-346

De Souza EB, Anholt RRH, Murphy KMM, Snyder SH, Kuhar MJ (1985): Peripheral-type benzodiazepine receptors in endocrine organs: Autoradiographic localization in rat pituitary, adrenal, and testis. Endocrinology 116:567-573

Drugan RC (1996): Peripheral benzodiazepine receptors: Molecular pharmacology to possible physiological significance in stress-induced hypertension. Clin Neuropharmacol 19:475-496

Drugan RC, Holmes PV, Scher DM, Luczak S, Oh H, Freland RJ (1995): Environmentally induced changes in peripheral benzodiazepine receptors are stressor and tissue specific. Pharmacol Biochem Behav 50:551-62

Drugan RC, Basile AS, Crawley JN, Paul SM, Skolnick P (1986): Inescapable shock reduces $\left[{ }^{3} \mathrm{H}\right]$ Ro 5-4864 binding to "peripheral-type" benzodiazepine receptors in the rat. Pharmacol Biochem Behav 24:1673-1677

Drugan RC, Basile AS, Crawley JN, Paul SM, Skolnick P (1987): "Peripheral" benzodiazepine binding sites in the Maudsley reactive rat: selective decrease confined to peripheral tissues. Brain Res Bull 18:143-145

Drugan RC, Basile AS, Crawley JN, Paul SM, Skolnick P (1988): Characterization of stress-induced alterations in $\left[{ }^{3} \mathrm{H}\right]$ Ro5-4864 binding to peripheral benzodiazepine receptors in rat heart and kidney. Pharmacol Biochem Behav 304:1015-1020

Drugan RC, Holmes PV, Stringer AP (1990): Pentobarbital blocks the stress-induced decrease in $\left[{ }^{3} \mathrm{H}\right]$ Ro $5-4864$ binding in rat kidney. Brain Res 535:151-154
Fares F, Gavish M (1986): Characterization of peripheral benzodiazepine binding sites in human term placenta. Biochem Pharmacol 35:227-230

Ferrarese C, Mennini T, Pecora N, Pierpaoli C, Frigo M, Marzorati C, Gobbi M, Bizzi A, Codegoni A, Garattini S, Frattola L (1991): Diazepam binding inhibitor (DBI) increases after acute stress in rat. Neuropharmacology 30:1445-1452

Ferretti C, Blengio M, Gamalero SR, Ghi P (1995): Biochemical and behaviour changes induced by acute stress in a chronic variate stress model of depression: the effect of amitriptyline. Eur J Pharmacol 280:19-26

Gavish M, Katz Y, Bar-Ami S, Weizman R (1992): Biochemical, physiological, and pathological aspects of the peripheral benzodiazepine receptor. J Neurochem 58:1589-1601

Gavish M, Bar-Ami S, Weizman R (1993): Pathophysiological and endocrinological aspects of peripheral-type benzodiazepine receptors. In Giesen-Crouse E (ed), Peripheral benzodiazepine receptors. London, Academic Press, pp 209-234

Gavish M, Weizman R (1997): Role of peripheral-type benzodiazepine receptors in steroidogenesis. Clin Neuropharmacol 20:473-481

Gavish M, Bachman I, Shoukrun R, Katz Y, Veenman L, Weisinger G, Weizman A (1999): The enigma of the peripheral benzodiazepine receptor. Pharmacol Rev 51:619-650

Golani I, Weizman A, Leschiner S, Eckstein N, Limor R, Yanai J, Weisinger G, Gavish M (2001): Hormonal regulation of peripheral benzodiazepine receptor binding properties is mediated by subunit interaction. Biochemistry 40:10213-10222

Gonzalez AS, Rodrigo Echandia EL, Cabrera R, Foscolo MR, Francchia LN (1990): Neonatal chronic stress induces subsensitivity to chronic stress in adult rats. Effects on forced swim behavior and endocrine responses. Physiol Behav 47:735-741

Guilarte TR, Kuhlmann AC, O'Callaghan JP, Miceli RC (1995): Enhanced expression of peripheral benzodiazepine receptors in trimethyltin-exposed rat brain: A biomarker of neurotoxicity. Neurotoxicology 16:441-450

Harris RB, Zhou J, Youngblood BD, Smagin GN, Ryan DH (1997): Failure to change exploration or saccharin preference in rats exposed to chronic mild stress. Physiol Behav 63:91-100

Holmes PV, Drugan RC (1994): Stress-induced regulation of the renal peripheral benzodiazepine receptor: Possible role of the renin-angiotensin system. Psychoneuroendocrinology 19:43-54

Holmes PV, Stringer AP, Drugan RC (1992): Impact of psychological dynamics on the peripheral benzodiazepine receptor. Pharmacol Biochem Behav 42:437-444

Karp L, Weizman A, Tyano S, Gavish M (1989): Examination stress, platelet peripheral benzodiazepine binding sites, and plasma hormone levels. Life Sci 44:1077-1082

Kuhlmann AC, Guilarte TR (1997): The peripheral benzodiazepine receptor is a sensitive indicator of domoic acid neurotoxicity. Brain Res 751:281-288 
Lallement G, Carpentier P, Pernot-Marino I, Baubichon D, Collet A, Blanchet G (1993): Transient impairment of the gabaergic function during initiation of soman-induced seizures. Brain Res 629:239-244

Le Fur G, Vaucher N, Perrier ML, Flamier A, Benavides J, Renault C, Dubroeucq MC, Guérémy C, Uzan A (1983): Differentiation between two ligands for peripheral benzodiazepine binding sites, $\left[{ }^{3} \mathrm{H}\right] \mathrm{RO} 5-4864$ and $\left[{ }^{3} \mathrm{H}\right] \mathrm{PK}$ 11195 , by thermodynamic studies. Life Sci 33:449-457

Lehmann J, Weizman R, Pryce CR, Leschiner S, Allmann I, Feldon J, Gavish M (1999): Peripheral benzodiazepine receptors in cerebral cortex, but not in internal organs, are increased following inescapable stress and subsequent avoidance/escape shuttle-box testing. Brain Res 851:141-147

Lemoine AP, Armando I, Brun JC, Segura ET, Barontini M (1990): Footshock affects heart and brain MAO and MAO inhibitory activity and open field behavior in rats. Pharmacol Biochem Behav 36:85-88

Mestre M, Carriot T, Belin C, Uzan A, Renault C, Dubroeucq MC, Guérémy C, Doble A, Le Fur G (1985): Electrophysiological and pharmacological evidence that peripheral type benzodiazepine receptors are coupled to calcium channels in the heart. Life Sci 36:391-400

Möhler H, Okada T (1977): Benzodiazepine receptor: Demonstration in the central nervous system. Science 198:849-851

Motohashi N, Okamoto Y, Osada M, Yamawaki S (1993): Acute swim stress increases benzodiazepine receptors, but not GABA-A or GABA-B receptors, in the rat cerebral cortex. Neurochem Int 23:327-330

Moura MJ, De Moraes S (1994): Forced swim stress: supersensitivity of the isolated rat pacemaker to the chronotropic effect of isoprenaline and the role of corticosterone. Gen Pharmacol 25:1341-1347

Nagy L, Fiegler M, Mozsik G, Nemeth M, Ruzsa CS, Gerber E, Javor T (1983): Some metabolic and biochemical alterations during the development of stress ulcers in rats forced to swim. Int J Tissue React 5:363-371

Novas ML, Medina JH, Calvo D, De Robertis E (1987): Increase of peripheral type benzodiazepine binding sites in kidney and olfactory bulb in acutely stressed rats. Eur J Pharmacol 135:243-246

Okun F, Weizman R, Katz Y, Bomzon A, Youdim MBH, Gavish M (1988): Increase in central and peripheral benzodiazepine receptors following surgery. Brain Res 458:31-36

Pandossio JE, Molina VA, Brandao ML (2000): Prior electrical stimulation of the inferior colliculus sensitizes rats to the stress of the elevated plus-maze test. Behav Brain Res 109:19-25

Papadopoulos V, Amri H, Boujrad N, Cascio C, Culty M, Garnier M, Hardwick M, Li H, Vidic B, Brown AS, Reversa JL, Bernassau JM, Drieu K (1997): Peripheral benzodiazepine receptor in cholesterol transport and steroidogenesis. Steroids 62:21-8

Papadopoulos V, Widmaier EP, Amri H, Zilz A, Li H, Culty M, Castello R, Philip GH, Sridaran R, Drieu K (1998): In vivo studies on the role of the peripheral benzodiazepine receptor (PBR) in steroidogenesis. Endocr Res 24:479-487
Pellow S, Chopin P, File SE, Briley M (1985): Validation of open:closed arm entries in an elevated plus-maze as a measure of anxiety in the rat. J Neurosci Methods 14:149-167

Purdy RH, Morrow AL, Moore Jr PR, Paul SM (1991): Stressinduced elevations of $\gamma$-aminobutyric acid type $A$ receptor-active steroids in the rat brain. Proc Natl Acad Sci 88:4553-4557

Rägo L, Kiivet R-A, Harro J, Pold M (1989): Central- and peripheral-type benzodiazepine receptors: similar regulation by stress and GABA receptor agonists. Pharmacol Biochem Behav 32:879-883

Rägo L, Adojaan A, Harro J, Kiivet R-A (1991): Correlation between exploratory activity in an elevated plus-maze and number of central and peripheral benzodiazepine binding sites. Naunyn Schmiedeberg's Arch Pharmacol 343:301-306

Shors TJ, Pickett J, Wood G, Paczynski M (1999): Acute stress persistently enhances estrogen levels in the female rat. Stress 3:163-171

Shors TJ (2001): Acute stress rapidly and persistently enhances memory formation in the male rat. Neurobiol Learn Mem 75:10-29

Song C, Earley B, Leonard BE (1995): Behavioral, neurochemical, and immunological responses to CRF administration. Is CRF a mediator of stress? Ann N Y Acad Sci 771:55-72

Squires RF, Braestrup C (1977): Benzodiazepine receptors in rat brain. Nature 266:732-734

Stout JC, Weiss JM (1994): An animal model for measuring behavioral responses to anxiogenic and anxiolytic manipulations. Pharmacol Biochem Behav 47:459-465

Vázquez DM, Van Oers H, Levine S, Akil H (1996): Regulation of glucocorticoid and mineralocorticoid receptor mRNAs in the hippocampus of the maternally deprived infant rat. Brain Res 731:79-90

Veenman L, Gavish M (2000): Peripheral benzodiazepine receptors: Their implication in brain disease. Drug Dev Res 50:355-370

Verma A, Snyder SH (1989): Peripheral type benzodiazepine receptors. Annu Rev Pharmacol Toxicol 29:307-322

Weizman R, Weizman A, Kook KA, Vocci F, Deutsch SI, Paul SM (1989): Repeated swim stress alters brain benzodiazepine receptors measured in vivo. J Pharmacol Exp Ther 249:701-707

Weizman A, Bidder M, Fares F, Gavish M (1990a): Food deprivation modulates $\gamma$-aminobutyric acid receptors and peripheral benzodiazepine binding sites in rats. Brain Res 535:96-100

Weizman A, Weizman R, Kook KA, Vocci F, Deutsch SI, Paul SM (1990b): Adrenalectomy prevents the stressinduced decrease in in vivo [3H]Ro15-1788 binding to GABAA benzodiazepine receptors in the mouse. Brain Res 519:347-350

Weizman R, Gavish M (1993): Molecular cellular and behavioral aspects of peripheral-type benzodiazepine receptors. Clin Neuropharmacol 16:401-417

Weizman R, Lehmann J, Leschiner S, Allmann I, Stoehr T, Heidbreder C, Domeney A, Feldon J, Gavish M (1999): Long-lasting effect of early handling on the peripheral 
benzodiazepine receptor. Pharmacol Biochem Behav 64:725-729

Wilson MA, Biscardi R (1994): Sex differences in GABA/ benzodiazepine receptor changes and corticosterone release after acute stress in rats. Exp Brain Res 101:297306

Zelena D, Haller J, Halász J, Makara GB (1999): Social stress of variable intensity: physiological and behavioral consequences. Brain Res Bull 48:297-302

Zilz A, Li H, Castello R, Papadopoulos V, Widmaier EP (1999): Developmental expression of the peripheraltype benzodiazepine receptor and the advent of steroidogenesis in rat adrenal glands. Endocrinology 140:859-864 